\title{
Perception of Country Tourism on Tourism Quality in Lake Toba North Sumatera 2020
}

\author{
Solahuddin Nasution' ${ }^{1}$, Samerdanta Sinulingga ${ }^{2}$, Arwina Sufika $^{3}$ \\ ${ }^{1,2,3}$ Universitas Sumatera Utara, Indonesia \\ solah_nasution@yahoo.com,danta@usu.ac.id
}

\begin{abstract}
The tourism industry as a foreign exchange earner for the non-oil and gas sector in Indonesia has contributed US \$16.426 billion in 2018 or around 200 trillion rupiahs. North Sumatra Province is one of the government's priorities in the tourism sector, measured from the construction of Sisingamangaraja XII International Airport in Silangit, the establishment of the Lake Toba Super Priority National Tourism Strategic Area (KSPN). The current Ministry of Tourism has made significant reforms, namely changing the focus from quantity tourism to quality tourism. The development of tourism quality that is currently underway in the Lake Toba area is then measured from the perceptions of tourists who respond to the quality values they have received while in the tourist area of Lake Toba. The theory used in this research is the theory of tourism by Nare, and the theory offoreign tourists by Ghanem. Furthermore, the method used is the quantitative data analysis method. Based on the results of the study it was found that the Cronbach's Alpha value was 0.931>0.60, so as the basis for decision making in the reliability test, it can be concluded that the data tested was reliable or consistent and reliable. Tourism actors involved in the research were also mostly tourism actors in 2004, so based on their answers it was found that there was a significant change in perceptions of foreign tourists, namely $0.931 \%$.
\end{abstract}

Keywords

tourism foreign tourists perceptions, North Sumatra; quality of tourism

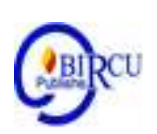

\section{Introduction}

Tourism is an industrial sector which is currently got a lot of attention from many countries in the world. The tourism sector is believed to have the ability to increase economic growth (Maciej Debski 2013). Moreover, the tourism sector is positively encouraged to be able to replace the oil and gas sector which has been the main capital in the country's foreign exchange earnings (Siswanto 2007). The advantage of the tourism sector lies in its ability to increase foreign exchange and to drive various other business sectors such as the home industry. Thus, developed countries and developing countries continue to develop and improve the quality of their country's tourism (Amin et al, 2019).

Tourism is one of the determinants of national economic growth because it can influence the growth of other sectors in the economy (Gokovali \& Bahar, 2006) and also grows very fast during this decade (Dogru \& Bulut, 2018; Wu et al., 2000). Sustainable tourism development can be completed by creating opportunities through networking and cooperation with service providers, where stakeholder engagement, the development of locally oriented codes of conduct, and local government participation are crucial factors for sustainable tourism success (Welford \& Ytterhus in Nurlina, 2020).

The tourism industry as a foreign exchange earner for the non-oil and gas sector in Indonesia has contributed the US \$16,426 billion in 2018 or around 200 trillion rupiah so that the Indonesian government is very serious about working on tourism as a core industry, 
including an increase in government activity which has a positive effect on the tourism industry in America (2014). The World Travel \& Tourism Council announced in 2019 that Indonesian tourism is the fastest growing industry, which is ranked 9th in the world, number three in Asia, and number one in the Southeast Asia region, also included in The Top 20 Fastest-Growing Travel Destinations according to the British newspaper The Telegraph (Fahlevi, 2018).

North Sumatra Province is one of the government's priorities in the tourism sector, measured from the construction of Sisingamangaraja XII International Airport in Silangit, the establishment of the National Tourism Strategic Area (KSPN) Super Priority for Lake Toba with a budget of up to 1.5 trillion rupiahs, the proposal of Lake Toba to UNESCO as a Global Geopark, Ya'ahowu Nias Festival 2019, the title of Malay Allied, and others. All these development activities lead us to one question: whether all tourism development, financial support, the establishment of an authorized body, and the legitimacy of UNESCO have an impact on quality tourism in North Sumatra, the Government of Indonesia (2021).

This is necessary considering the current Ministry of Tourism has made significant reforms, namely changing its focus from quantity tourism to quality tourism. According to Gilmore (2017), Khuong (2017), and Foris et al., (2018), the quality of tourism is defined by the characteristics of tourism services, tourism service products, and the unique features provided and displayed by a tourist area. These indicators are measured in organized tours, tourist activities, tourist facilities, and tourist services provided by stakeholders to tourists visiting the locations they visit.

The tourism quality standards set by the Government of Indonesia are 1) foreign exchange and tourism added value; 2) readiness of destinations, industry, and society; 3) human resource capacity; 4) environmental carrying capacity; 5) competitive image of the archipelago tourism. Also considering that 2020 is the movement of the industrial revolution 4.0 which certainly greatly affects tourist behavior, generally tourists want ease and speed in accessing information and services. These tourists are then referred to as millennial tourists, with their mobile, personal, and interactive characteristics (Sinulingga, 2020).

Data on the level of foreign tourist visits 244,530 people who enter through the airport at Kuala Namu Airport in 2019 (www.bps.go.id) and the target of achieving 20 million foreign tourist visits, are opportunities for improving tourism quality. Based on this background, this research will complete previous research on Persepsi International Tourists against the Quality of North Sumatra Tourism in 2005.

\section{Research Methods}

The research method used in this research is quantitative data research. According to Sugiyono (2012: 13): "Quantitative data is a characteristic of a variable whose values are expressed in numerical form." by using simple linear regression analysis techniques. In this study, only one variable was used, namely the perception of foreign tourists on the quality of tourism in North Sumatra in 2020.

Initial research was carried out by collecting material from various sources after going through problem identification. The sources used are books, journals, documents, and the distribution of questionnaires or questionnaires. In this study, the researchers distributed questionnaires using online tools (Google form and email) to 100 who were registered as International Tourists who were clients of ASITA North Sumatra member tourism businesses. Make use of online tools sent to foreign tourists who have visited North Sumatra. Furthermore, the data is processed, to obtain facts and answers to the formulation of problems in the field. 


\section{Results and Discussion}

\subsection{Frequency Table Analysis}

Table 1. The Frequency of Respondents' Answers about the Quality of Visible Tourist Attractions

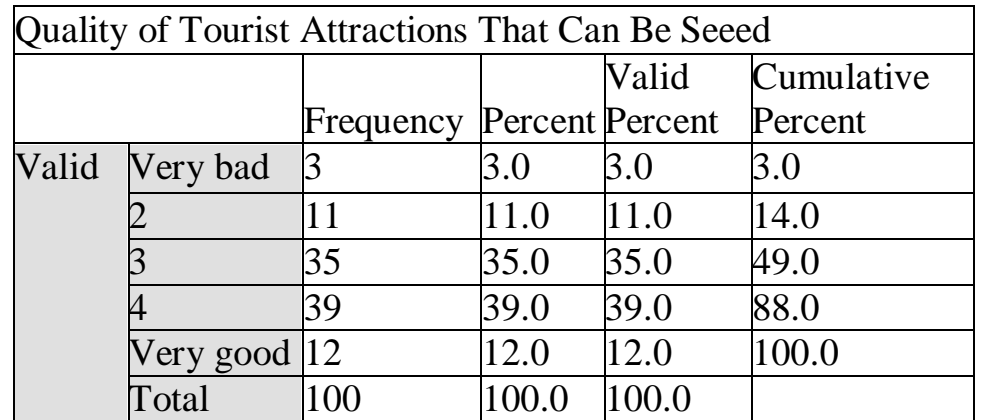

Source: Data processed using SPSS Version 25

Based on the table above, it can be seen that of the 100 respondents, 39 (39\%) answered that the quality of tourist attractions that can be seen is good. This can be seen based on the value given is 4 , which means that it is almost close to 5 (very good). Furthermore, it can be included in the category with moderate answers as many as 35 people (35\%). Very good as many as 12 people (12\%), close to very bad as many as 11 people (11\%), and answered Very Bad as many as 3 people (3\%).

Table 2. The Frequency of Respondents' Answers about the Quality of Attractions That Can Be Done

\begin{tabular}{|l|l|l|l|l|l|}
\hline \multicolumn{6}{|l|}{ Quality of Attractions That Can Be Done } \\
\hline \multicolumn{1}{|c|}{} & & & & Valid & Cumulative \\
Pequency & Percent & Percent & Percent \\
\hline Valid & Very bad & 1 & 1.0 & 1.0 & 1.0 \\
\cline { 2 - 6 } & 2 & 16 & 16.0 & 16.0 & 17.0 \\
\cline { 2 - 6 } & 3 & 44 & 44.0 & 44.0 & 61.0 \\
\cline { 2 - 6 } & 4 & 28 & 28.0 & 28.0 & 89.0 \\
\cline { 2 - 6 } & Very good & 11 & 11.0 & 11.0 & 100.0 \\
\cline { 2 - 6 } & & & & & \\
\cline { 2 - 6 } & Total & 100 & 100.0 & 100.0 & \\
\hline
\end{tabular}

Source: Data processed using SPSS Version 25

Based on the table above, it can be seen that from 100 respondents, 44 people (44\%) answered that the quality of tourist attractions that can be done is quite good or moderate. This can be seen based on the value given is 3 , which means that it is almost close to 4 (good). Furthermore, 28 people (28\%) answered well. Meanwhile, approaching very bad was 16 people $(16 \%)$, very good as many as 11 people $(11 \%)$, and answered very bad as many as 1 person $(1 \%)$. 
Table 3. The Frequency of Respondents' Answers about the Quality of Natural Tourism Attractions

\begin{tabular}{|l|l|l|l|l|l|}
\hline \multicolumn{6}{|l|}{ Quality of Natural Tourist Attractions } \\
\hline \multicolumn{1}{|c|}{} & Frequency & Percent & Valid Percent & Cumulative Percent \\
\hline Valid & 2 & 9 & 9.0 & 9.0 & 9.0 \\
\cline { 2 - 6 } & 3 & 26 & 26.0 & 26.0 & 35.0 \\
\cline { 2 - 6 } & 4 & 39 & 39.0 & 39.0 & 74.0 \\
\cline { 2 - 6 } & Very good & 26 & 26.0 & 26.0 & 100.0 \\
\cline { 2 - 6 } & Total & 100 & 100.0 & 100.0 & \\
\hline
\end{tabular}

Source: Data processed using SPSS Version 25

Based on the table above, it can be seen that of the 100 respondents, 39 people $(39 \%)$ answered that the quality of natural tourist attractions was good. This can be seen based on the value given is 4 , which means that it is almost close to 5 (very good). Furthermore, it can be included in the category with moderate answers as many as 26 people $(26 \%)$. Very good as many as 26 people (26\%), close to very bad as many as 9 people (9\%), and answered Very Bad as many as 0 people $(0 \%)$.

Table 4. The Frequency of Respondents' Answers about the Quality of Cultural Tourism Activities

\begin{tabular}{|l|l|l|l|l|l|}
\hline \multicolumn{6}{|l|}{ Quality of Cultural Tourism Activities } \\
\hline \multicolumn{1}{|c|}{} & Frequency & Percent & Valid Percent & Cumulative Percent \\
\hline Valid & Very bad & 2 & 2.0 & 2.0 & 2.0 \\
\cline { 2 - 6 } & 2 & 16 & 16.0 & 16.0 & 18.0 \\
\cline { 2 - 6 } & 3 & 30 & 30.0 & 30.0 & 48.0 \\
\cline { 2 - 6 } & 34 & 34.0 & 34.0 & 82.0 \\
\cline { 2 - 6 } & Very good & 18 & 18.0 & 18.0 & 100.0 \\
\cline { 2 - 6 } & Total & 100 & 100.0 & 100.0 & \\
\hline
\end{tabular}

Source: Data processed using SPSS Version 25

Based on the table above, it can be seen that of the 100 respondents involved in this study, 34 people (34\%) answered that the quality of cultural tourism activities was good. This can be seen based on the value given is 4 , which means that it is almost close to 5 (very good). Furthermore, it can be included in the category with moderate answers as many as 30 people (30\%). While 18 people were very good (18\%), approached very badly as many as 16 people $(16 \%)$, and answered Very Bad as many as 2 people $(2 \%)$.

Table 5. The Frequency of Respondents' Answers about the Quality of Man-Made Tourism Activities

\begin{tabular}{|c|c|c|c|c|c|}
\hline \multicolumn{6}{|c|}{ Quality of Man-Made Tourism Activities } \\
\hline & & Frequency & Percent & Valid Percent & Cumulative Percent \\
\hline \multirow[t]{6}{*}{ Valid } & Very bad & 3 & 3.0 & 3.0 & 3.0 \\
\hline & 2 & 17 & 17.0 & 17.0 & 20.0 \\
\hline & 3 & 50 & 50.0 & 50.0 & 70.0 \\
\hline & 4 & 21 & 21.0 & 21.0 & 91.0 \\
\hline & Very good & 9 & 9.0 & 9.0 & 100.0 \\
\hline & Total & 100 & 100.0 & 100.0 & \\
\hline
\end{tabular}

Source: Data processed using SPSS Version 25 
Based on the table above, it can be seen that of the 100 respondents, 50 people $(50 \%)$ answered that the quality of man-made tourist attractions is quite good or moderate. This can be seen based on the value given is 3 , which means that it is almost close to 4 (good). Furthermore, 21 people (21\%) answered well. Meanwhile, approaching very bad was 17 people $(17 \%)$, very good as many as 11 people $(11 \%)$, and answered very bad as many as 3 people $(3 \%)$.

Table 6. Basic Respondent's Response Frequency (Toilet, Telecommunication, Electricity, and Quality of Needs Facilities

\begin{tabular}{|c|c|c|c|c|c|}
\hline \multicolumn{6}{|c|}{$\begin{array}{l}\text { Quality of Basic Needs Facilities (Toilets, Telecommunications, Electricity and } \\
\text { the Like) }\end{array}$} \\
\hline & & Frequency & Percent & Valid Percent & Cumulative Percent \\
\hline \multirow[t]{6}{*}{ Valid } & Very bad & 7 & 7.0 & 7.0 & 7.0 \\
\hline & 2 & 27 & 27.0 & 27.0 & 34.0 \\
\hline & 3 & 37 & 37.0 & 37.0 & 71.0 \\
\hline & 4 & 20 & 20.0 & 20.0 & 91.0 \\
\hline & Very good & 9 & 9.0 & 9.0 & 100.0 \\
\hline & Total & 100 & 100.0 & 100.0 & \\
\hline
\end{tabular}

Source: Data processed using SPSS Version 25

Based on the table above, it can be seen that of the 100 respondents, 37 people $(37 \%)$ answered that the quality of basic needs facilities (toilets, telecommunications, electricity, and the like) was quite good or moderate. This can be seen based on the value given is 3 , which means that it is almost close to 4 (good). Furthermore, it can be included in the category that answers very badly as many as 27 people (27\%). Meanwhile, close to very good as many as 20 people (20\%), very good as many as 9 people $(9 \%)$, and very bad answer as many as 7 people $(7 \%)$.

Table 7. Frequency of Respondents' Answers on the Quality of Transportation Facilities (Road Access and Mobility

\begin{tabular}{|c|c|c|c|c|c|}
\hline \multicolumn{6}{|c|}{ Quality of Transportation Facilities (Access and Road Mobility) } \\
\hline & & Frequency & Percent & Valid Percent & Cumulative Percent \\
\hline \multirow[t]{6}{*}{ Valid } & Very bad & 3 & 3.0 & 3.0 & 3.0 \\
\hline & 2 & 14 & 14.0 & 14.0 & 17.0 \\
\hline & 3 & 54 & 54.0 & 54.0 & 71.0 \\
\hline & 4 & 21 & 21.0 & 21.0 & 92.0 \\
\hline & Very good & 8 & 8.0 & 8.0 & 100.0 \\
\hline & Total & 100 & 100.0 & 100.0 & \\
\hline
\end{tabular}

Source: Data processed using SPSS Version 25

Based on the table above, it can be seen that from 100 respondents, 54 people (54\%) answered that the quality of transportation facilities (road access and mobility) was quite good or moderate. This can be seen based on the value given is 3 , which means that it is almost close to 4 (good). Furthermore, 21 people (21\%) answered well. Meanwhile, there were 14 people $(14 \%)$ close to very bad, 8 people $(8 \%)$ very good, and 3 people answered very bad (3\%). 
Table 8. The Frequency of Respondents' Answers about the Quality of Hospitality Facilities (Accommodation, Restaurants and the Like)

\begin{tabular}{|c|c|c|c|c|c|}
\hline \multicolumn{6}{|c|}{ Quality of Hospitality Facilities (Accommodation, Restaurants and the Like) } \\
\hline & & Frequency & Percent & Valid Percent & Cumulative Percent \\
\hline \multirow{6}{*}{ Valid } & Very bad & 3 & 3.0 & 3.0 & 3.0 \\
\hline & 2 & 5 & 5.0 & 5.0 & 8.0 \\
\hline & 3 & 48 & 48.0 & 48.0 & 56.0 \\
\hline & 4 & 35 & 35.0 & 35.0 & 91.0 \\
\hline & Very good & 9 & 9.0 & 9.0 & 100.0 \\
\hline & Total & 100 & 100.0 & 100.0 & \\
\hline
\end{tabular}

Source: Data processed using SPSS Version 25

Based on the table above, it can be seen that of the 100 respondents, as many as 48 people (48\%) answered that the quality of hospitality facilities (accommodation, restaurants, and the like) was quite good or moderate. This can be seen based on the value given is 3 , which means that it is almost close to 4 (good). Furthermore, it can be included in the category that answered well as many as 35 people (35\%). Meanwhile, 9 people were very good (9\%), close to very bad as many as 5 people $(5 \%)$, and answered very bad as many as 3 people $(3 \%)$.

Table 9. The Frequency of Respondents' Answers about the Quality of Human Resources (HR) in Tourism

\begin{tabular}{|c|c|c|c|c|c|}
\hline \multicolumn{6}{|c|}{ Quality of Human Resources (Hr) Tour Guides } \\
\hline & & Frequency & Percent & Valid Percent & Cumulative Percent \\
\hline \multirow[t]{5}{*}{ Valid } & 2 & 14 & 14.0 & 14.0 & 14.0 \\
\hline & 3 & 46 & 46.0 & 46.0 & 60.0 \\
\hline & 4 & 33 & 33.0 & 33.0 & 93.0 \\
\hline & Very good & 7 & 7.0 & 7.0 & 100.0 \\
\hline & Total & 100 & 100.0 & 100.0 & \\
\hline
\end{tabular}

Based on the table above, it can be seen that from 100 respondents, 46 people $(46 \%)$ answered that the quality of human resources (HR) was quite good or moderate. This can be seen based on the value given is 3 , which means that it is almost close to 4 (good). Furthermore, it can be included in the category that answers close to very good as many as 33 people (33\%). Meanwhile, close to very bad as many as 14 people (14\%), Very good as many as 7 people $(7 \%)$, and answered Very Bad as many as 0 people $(0 \%)$.

Table 10. The Frequency of Respondents' Answers about the Quality of Human Resources (HR) of the Community around the Tourism Location

\begin{tabular}{|c|c|c|c|c|c|}
\hline \multicolumn{6}{|c|}{$\begin{array}{l}\text { Sumer Quality of Human Resources (Sdm) of the Community Around the } \\
\text { Tourist Site }\end{array}$} \\
\hline & & Frequency & Percent & Valid Percent & Cumulative Percent \\
\hline \multirow[t]{6}{*}{ Valid } & Very bad & 3 & 3.0 & 3.0 & 3.0 \\
\hline & 2 & 25 & 25.0 & 25.0 & 28.0 \\
\hline & 3 & 47 & 47.0 & 47.0 & 75.0 \\
\hline & 4 & 21 & 21.0 & 21.0 & 96.0 \\
\hline & Very good & 4 & 4.0 & 4.0 & 100.0 \\
\hline & Total & 100 & 100.0 & 100.0 & \\
\hline
\end{tabular}

Source: Data processed using SPSS Version 25 
Based on the table above, it can be seen that of the 100 respondents, 47 (47\%) answered that the quality of the human resources (HR) of the community around the tourist location was quite good or moderate. This can be seen based on the value given is 3 , which means that it is almost close to 4 (good). Furthermore, 25 people (25\%) answered very badly. Meanwhile, close to very good as many as 21 people $(21 \%)$, very good as many as 4 people (4\%), and very bad answer as many as 3 people (3\%).

Table 11. Frequency of Respondents' Answers about the Quality of Tourism Information Center Services

\begin{tabular}{|c|c|c|c|c|c|}
\hline \multicolumn{6}{|c|}{ Service Quality of tourist information center } \\
\hline & & Frequency & Percent & Valid Percent & Cumulative Percent \\
\hline \multirow[t]{6}{*}{ Valid } & Very bad & 14 & 14.0 & 14.0 & 14.0 \\
\hline & 2 & 12 & 12.0 & 12.0 & 26.0 \\
\hline & 3 & 41 & 41.0 & 41.0 & 67.0 \\
\hline & 4 & 30 & 30.0 & 30.0 & 97.0 \\
\hline & Very good & 3 & 3.0 & 3.0 & 100.0 \\
\hline & Total & 100 & 100.0 & 100.0 & \\
\hline
\end{tabular}

Source: Data processed using SPSS Version 25

Based on the table above, it can be seen that from 100 respondents, 41 people $(41 \%)$ answered that the quality of tourism information center services was quite good or moderate. This can be seen based on the value given is 3 , which means that it is almost close to 4 (good). Furthermore, it can be included in the category that answers close to very good as many as 30 people (30\%). Meanwhile, as many as 14 people (14\%) were very bad, close to very bad as many as 12 people (12\%), and answered Very Good as many as 3 people (3\%).

Table 12. Frequency of Respondents' Answers on Government Support for the Private Sector

\begin{tabular}{|c|c|c|c|c|c|}
\hline \multicolumn{6}{|c|}{ Support From Government For Private } \\
\hline & & Frequenc & Percent & Valid Percent & Cumulative Percent \\
\hline \multirow[t]{6}{*}{ Valid } & Very bad & 9 & 9.0 & 9.0 & 9.0 \\
\hline & 2 & 17 & 17.0 & 17.0 & 26.0 \\
\hline & 3 & 33 & 33.0 & 33.0 & 59.0 \\
\hline & 4 & 33 & 33.0 & 33.0 & 92.0 \\
\hline & Very good & 8 & 8.0 & 8.0 & 100.0 \\
\hline & Total & 100 & 100.0 & 100.0 & \\
\hline
\end{tabular}

Source: Data processed using SPSS Version 25

Based on the table above, it can be seen that of the 100 respondents, 33 people $(33 \%)$ answered that the quality of tourism information center services was quite good or moderate. This can be seen based on the value given is 3 , which means that it is almost close to 4 (good). Furthermore, it can be included in the category that answers nearly very well as many as 33 people (33\%). Meanwhile, there were 17 people (17\%) close to very bad, 9 people $(9 \%)$ very bad, and 8 people answered Very Well (8\%).

\section{a. Validity Test}

Based on the Sig. (2-tailed) <0, 05 (less than 0.05) and Pearson Correlation is positive. The value of the $r$ count is 0.728 . This shows that the data used is valid and can be trusted. However, to maximize the validity of the data, the following $r$ table will also be used. The result is 0.677 , where the $t$ table result is smaller $(<)$ than the t count, which is 0.728 . By the results of the validity test, it was found; If the value of $r$ count $>r$ table, then the item in the questionnaire is declared valid. 
Table 13. Reliability Statistics

\begin{tabular}{|l|l|}
\hline Reliability Statistics \\
\hline Cronbach's Alpha & N of Items \\
\hline .931 & 12 \\
\hline
\end{tabular}

Source: Data processed using SPSS Version 25

Through the results of the reliability test analysis, it was found that the Cronbach Alpha was $0.931>0.6$. This shows that the data contained in the research are reliable, that is, they can be trusted.

\section{Conclusion}

The conclusions of this study are as follows:

1. Based on the Sig. (2-tailed) $<0.05$ (less than 0.05) and the Pearson Correlation is positive. The value of the $r$ count is 0.728 . This shows that the data used is valid and can be trusted. However, to maximize the validity of the data, the following $r$ table will also be used.

2. Based on the $t$ table, the result is 0.677 , where the $t$ table result is smaller $(<)$ than the $t$ count, which is 0.728 . By the withdrawal of the validity test results, it is found; If the value of $r$ count $>r$ table, then the item in the questionnaire is declared valid

3. Through the results of the reliability test analysis, it was found that the Cronbach Alpha was $0.931>0.6$. This shows that the data contained in the research are reliable, that is, they can be trusted.

4. Based on $\mathrm{N}$ of items (the number of question items as many as 12 questions with a Cronbach's Alpha value of $0.931>0.60$, as the basis for decision making in the reliability test, it can be concluded that the 12 question items are reliable or consistent. As for each item of questions, which are known to $\mathrm{N}$ of items (the number of questions is 12 questions with a Cronbach's Alpha value of 0.931>0.60, it can be concluded that the 12 question items are reliable or consistent.

\section{Suggestion}

The suggestions for this research are

1. You should the tourism industry is a significant foreign exchange earner for the non-oil and gas sector in Indonesia, the government should pay more attention to its development. Not only for tourists who come to visit but also for foreign tourists themselves.

2. Improving the quality of tourism in North Sumatra can be done by involving various tourism stakeholders who have been at the forefront of the tourism industry in North Sumatra. 


\section{References}

Amin, M et al. (2019). Marketing Communication Strategy to Improve Tourism Potential. Budapest International Research and Critics Institute-Journal (BIRCI-Journal). P. 160166.

Amerta, I., \& Budhiasa, I. (2014). The Influence of Visits of International Tourists, Domestic Tourists, Number of Hotels, and Other Accommodations on Regional Original Income (PAD) in Badung Regency 2001-2012. E-Journal of University Development Economics Udayana. Retrieved from https://ojs.unud.ac.id/index.php/eep/article/view/7567

Fahlevi, Reza. (2018). Central Kalimantan Tourism Development. Retrieved January 09, 2021, fromhttp://bappeda.jabarprov.go.id/wp-content/uploads/2019/04/2.-RencanaPengembangan-Kawasan-Ekonomi-Khusus-Kek-Pariwisata-Di-Jawa-Barat.pdf.

Foris, Diana \& Popescu, Maria \& Foris, Tiberiu. (2018). A Comprehensive Review of the Quality Approach in Tourism.http://dx.doi.org/10.5772/intechopen.70494

Gilmore, Audrey. (2017). Quality and Quantity in Tourism. Journal of Hotel \& Business Management (6: 1).https://doi.org/10.4172/2169-0286.1000164

Indonesian government. (2009). Law No. 10 of 2009 concerning Tourism. Ministry of Tourism and Creative Economy.

Indonesian government. (2021). Data on Tourist Visits through Kuala Namu Airport in 2019. Retrieved January 10, 2021, fromhttps://www.bps.go.id

Indonesian government. (2021). Integrated Tourism Masterplan for Lake Toba. Retrieved January 09, 2021, fromhttps://bpiw.pu.go.id/uploads/temp/Konsep_Pengembangan_W Wilayah_dan_Infrastruktur_KSPN_Danau_Toba.pdf

Khuong, Mai Ngoc and Nguyen Thanh Phuong. (2017). The Effects of Destination Image, Perceived Value, and Service Quality on Tourist Satisfaction and Word-of-Mouth - A Study in Ho Chi Minh City, Vietnam. International Journal of Trade, Economics and Finance, Vol. 8, No. 5, October 2017.https://doi.org/10.18178/ijtef.2017.8.5.568

Nurlina, (2020). Tourism Development in Langsa, Indonesia: An Overview of Tourist Attractions and Accommodation. Budapest International Research and Critics InstituteJournal (BIRCI-Journal). P.923-931

Sinulingga, S., Pardosi, J., Bangun, N., \& Siahaan, H. (2020). Making Tourism Films as a Tourism Promotion Media in Rumah Galuh Village, Langkat Regency. Journal of the $\begin{array}{llllll}\text { Master of Tourism (JUMPA), } & \text { Vol. }\end{array}$ 374.https://doi.org/10.24843/JUMPA.2020.v06.i02.p06

Sugiono. (2002). Business Research Methods. Bandung: Alfabeta. 